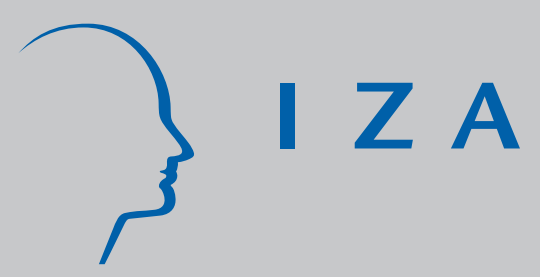

IZA DP No. 99

Residential Location and Youth Unemployment: The Economic Geography of School-To-Work Transitions

Regina T. Riphahn

December 1999 


\title{
Residential Location and Youth Unemployment: The Economic Geography of School-To-Work Transitions
}

\author{
Regina T. Riphahn \\ University of Munich, CEPR, London and IZA, Bonn
}

Discussion Paper No. 99

December 1999

\author{
IZA \\ P.O. Box 7240 \\ D-53072 Bonn \\ Germany \\ Tel.: +49-228-3894-0 \\ Fax: +49-228-3894-210 \\ Email: iza@iza.org
}

This Discussion Paper is issued within the framework of IZA's research area Mobility and Flexibility of Labor Markets. Any opinions expressed here are those of the author(s) and not those of the institute. Research disseminated by IZA may include views on policy, but the institute itself takes no institutional policy positions.

The Institute for the Study of Labor (IZA) in Bonn is a local and virtual international research center and a place of communication between science, politics and business. IZA is an independent, nonprofit limited liability company (Gesellschaft mit beschränkter Haftung) supported by the Deutsche Post AG. The center is associated with the University of Bonn and offers a stimulating research environment through its research networks, research support, and visitors and doctoral programs. IZA engages in (i) original and internationally competitive research in all fields of labor economics, (ii) development of policy concepts, and (iii) dissemination of research results and concepts to the interested public. The current research program deals with (1) mobility and flexibility of labor markets, (2) internationalization of labor markets and European integration, (3) the welfare state and labor markets, (4) labor markets in transition, (5) the future of work, (6) project evaluation and (7) general labor economics.

IZA Discussion Papers often represent preliminary work and are circulated to encourage discussion. Citation of such a paper should account for its provisional character. 
IZA Discussion Paper No. 99

December 1999

\section{ABSTRACT \\ Residential Location and Youth Unemployment: The Economic Geography of School-To-Work Transitions *}

In response to increased international policy attention to youth unemployment this study investigates post-secondary school transitions of school leavers. Multinomial logit models are estimated for male and female German youth. The models control for individual, parent, and household characteristics, for those of the youth's region of residence and local labor markets. The findings suggest that immigrant youth has particularly low participation rates in continued education, and that youth unemployment is centered in high unemployment states and metropolitan areas. Recent changes in academic benefit policies do not seem to be correlated with changes in academic enrollment, whereas men's transitions to the military do reflect recent changes in defense policies.

JEL Classification: J24, J64, J68

Keywords: School-to-Work, youth unemployment, local labor markets

Regina T. Riphahn

Economics Department

University of Munich

Ludwigstr. 28RG

80539 Munich

Tel: 49-89-2180-2128

Fax: 49-89-33 6392

Email: Regina.Riphahn@selapo.vwl.uni-muenchen.de

\footnotetext{
* Helpful comments of Christian Dustmann, Jochen Mayer, Jan van Ours, Ralph Rotte, and Alessandra Venturini on earlier versions of this paper are gratefully acknowledged. Thomas Kasperski provided excellent research assistance.
} 


\section{Introduction}

As of 1998 youth unemployment in the European Union was at 19.1 percent of the youth labor force. The literature provides ample evidence on the lifetime scars early unemployment experiences leave on workers' labor market and criminal records (Ellwood 1982, Freeman and Rodgers 1999, for Germany Franz et al. 1997). This dramatic situation prompted government responses in several countries. France launched an ambitious youth unemployment program in 1997, which as of November 1998 covered 152,000 persons aiming at 350,000 by 2000 (OECD 1999a). The German government passed a "100,000 Jobs for Youth" program, with DM 2 bio allocated for the fiscal years 1999 and 2000 each.

With youth unemployment high on the policy agenda, it is important to understand its determinants and the potential role for labor market policies. So far, only a few studies investigated the labor market transitions of school leavers. The issue was discussed in the United Kingdom due to a concern about declining participation in continued education. The German case found attention in the United States following the Clinton administration's suggestion to install some features of the German apprenticeship system there (Clinton and Gore 1992). Overall, the existing studies are characterized by a high degree of specificity in their topics. Only few attempt to answer the broader questions of what young people do after leaving school, how their choices are affectedby the labor market situation in their time and region or by policy changes, and to what degree parental and household characteristics affect the transitions.

This study addresses these important issues at the example of Germany. It applies a comprehensive modelling approach to investigate the transition choices of all youth leaving school between 1984 and 1997, as observed in the German Socioeconomic Panel (GSOEP). This dataset permits the consideration of detailed household and parent background variables, which were omitted in prior analyses. The findings are relevant to the evaluation of the German government's "100,000 Jobs for Youth" program, as one of the criticisms of this program relates to the equal spreading of program activities across labor market regions. To the degree that local factors are important for the 
success of youth labor market entry, regional differentiations in active labor market policies may be required. Finally, the study evaluates whether changes in training grant and military policies affected school-to-work transition patterns.

The paper proceeds with a summary of the German institutional framework for school-towork transitions, and of policy changes, that may have affected transition decisions. It describes the German youth labor market, and the main features of the "100,000 Jobs for Youth" program. Section 3 reviews the theoretical background of this study in view of the existing literature. The dataset and the estimation strategy are outlined in section 4 and the results are discussed in section 5 . The study concludes with a summary, highlighting policy implications.

\section{Institutional Background}

(a) School-to-Work in Germany

In contrast to other countries, the German school system introduces differentiated educational tracks already after the first four grades of primary education. The tracks differ in their academic orientation and requirements. The basic school (Hauptschule) graduates individuals after six years of secondary education and is considered a preparation for blue collar occupations. The middle school (Realschule) also lasts six years and provides training for white collar jobs. Only the highest track (Gymnasium) provides another nine years of schooling. Graduating from the Gymnasium is a precondition for university studies. In addition, comprehensive schools (Gesamtschule) were introduced in the 1970s, where courses of different academic requirements can be mixed. These schools grant degrees of either track. Depending on the chosen track, individuals typically finish school aged 16 or 19. Of the 1.1 mio graduates in 19977 percent had not obtained even the basic school degree (Hauptschulabschluß), 25 percent graduated from basic school, 38 percent from middle school, and 22 percent from the Gymnasium (with the rest in the "other" category). Figure 1 presents recent developments in the distribution of school leavers with an overall shift to the higher tracks.

Once they leave school, individuals can choose from a number of alternative paths. This choice 
is restricted only for healthy young men above age 18 , who are typically drafted for military or conscientious objector service. The most common transition after school is that into apprenticeship training. Apprenticeships last between 2 and 4 years, and combine vocational on the job training with continued formal education in vocational schools (Berufsschule).

Particularly in the mid 1980s, when the German baby-boom generation left school, insufficient apprenticeship positions were available for school leavers. For them and to provide training for certain occupations without apprenticeship programs, vocational schools are available to meet excess demand for vocational training. These offer (i) fulltime general schooling for those not previously qualified for apprenticeships in a one year 'vocational preparation year' (Berufsvorbereitungsjahr) program. Here individuals can complete their basic school degree (Hauptschulabschluß). In a program (ii) called 'elementary vocational year' (Berufsgrundbil-dungsjahr) students may learn occupation-specific skills which - if successfully completed - allows them to shorten a later apprenticehip. The third type (iii) labelled 'special vocational school' (Berufsfachschule) offers a variety of training opportunities. About half the students there complete a vocational degree, one quarter participates in training leading to the middle school degree (Realschulabschluß), one fifth takes training which already requires the middle school degree, and less than ten percent get a degree ranked below the middle school degree (for detail see BMBF 1999, or Franz et al. 1997). More than fifty percent of the students graduating from these three vocational schools continue their education with an apprenticeship.

In addition to the military, apprenticeship, and vocational school options, school leavers may choose immediate employment without training, they may leave the labor force, become unemployed or may begin an academic education. Clearly, a variety of policies influences the transition decision. A policy affecting the decision to take up academic training is the financial support program Bafög. Since 1971 a federal law governs the benefits available to children of non-wealthy parents, who pursue an academic education. ${ }^{1}$ The law has been changed repeatedly, with the most influential adjustments in

1 The benefit program also provides payments to high school students and participants in certain vocational training programs under restricitive and complex regulations. Since most of the program expenditures are 
1983, when the program switched from grants to loans, and again in 1990 when it was stipulated that only half of the program benefits had to be repaid. Figure 2 indicates that in consequence of the 1983 change particularly the female share of school leavers going on to university declined. However, the fraction of university students increased again in subsequent years with a steep jump in 1990, when the new grant system was passed.

A set of policies likely to affect male school leavers' transition decision relates to the military draft. Most influential for transition decisions is the leniency in the requirements for physical fitness and the flexibility of postponing the draft to complete vocational and academic training. The evidence suggests that prior to the end of the cold war in 1990 the draft was rather strict. The size of the German army declined from half a million in the mid 1980s (West Germany) to about 350,000 soldiers (united Germany), as determined in the unification treaties after 1990 (Rotte 1996). At that time drafting procedures were loosened and the duration of military service was cut from 15 to 12 months in 1991. The treatment of draftees was tightened again in recent years (beginning in 1995) after the military engagements in Bosnia and Kosovo had caused an increase in the share of conscienious objectors (BREG 1996). The impact of these developments on individuals' transition decisions is analysed below.

(b) Youth Unemployment in an International Perspective

By international comparison youth unemployment in Germany is moderate. Table 1 describes the unemployment rates by agegroups across countries for 1990 and 1998. By OECD definitions Germany had very low overall and youth unemployment in 1990, and even in 1998, when it ranked sixth in overall unemployment, youth unemployment rates were among the lowest listed. Table 2 presents the ratios of youth unemployment to total unemployment across countries, and confirms the comparatively positive situation for German youths.

alloted to university students, the discussion focuses on this program aspect. For detail see BMA (1995) or Frerich and Frey (1996). 
Figures 3 and 4 present the development of east and west German unemployment rates over the last decades. Youth unemployment rates in the 20 to 24 agegroup almost permanently exceed overall unemployment and that of the younger agegroup, with a particularly striking difference in East Germany. ${ }^{2}$ West German developments mirror the demographic shifts in the population: During the early eighties, when the baby boomers flooded the labor market, their unemployment was acutely above the overall average. Since 1987 unemployment among the very young remained below average and those above age 20 slightly exceed overall unemployment rates. Splitting youth unemployment into its duration and incidence components SVR (1998) show that the average duration of youth unemployment is below and incidence rates above the national average. As of 1997 about one in three youths had experienced unemployment.

In order to gauge whether regional differences play a role in youth unemployment, Figure 5 presents the ratio of youth to overall unemployment rates, averaged across two types of west German states: The states of Berlin, Hamburg, and Bremen contain almost exclusively urban regions, whereas the others ${ }^{3}$ ('area states') combine urban and rural areas. Averaging relative unemployment rate ratios across city and area states shows that for the last two decades relative youth unemployment has been a more pressing problem in cities than in rural areas.

The increase in youth unemployment rates since 1990 has prompted the newly elected Schröder government in 1998 to install a broadly publicized "100,000 Jobs for Youths" program. The program (a) provides subsidies to firms who offer additional apprenticeship positions to unemployed youth, (b) offers training programs through regional employment offices, (c) provides funding for various types of vocational training. The program started Jan. 1, 1999, covers individuals up to age 25, and intends to focus on east Germany, were unemployment is particularly trenchant. While the

\footnotetext{
2 This may in part be due to the definitional exclusion of "apprenticeship seekers" from the ranks of the unemployed. Franz et al. (1997) show that their inclusion would drive up youth unemployment rates by about 20 percent.

3 Bavaria, Baden-Württemberg, Hesse, Lower Saxony, Northrhine-Westfalia, Rhineland-Palatinate, Saarland, Schleswig-Holstein.
} 
program had reached more than 170,000 youths by August 1999, the effectiveness of the measures is difficult to judge so soon after initiation. Critics point out that private sector employers free ride on the employment subsidies, that the program is run even in areas where unemployment is low, and that it only postpones young people's unemployment for at most one year, when the measures terminate. Most recently the OECD (1999b) pointed to the often discouraging results of labor market policies directed at youths, but lists success stories, as well. Clearly, the youth unemployment issue is high on the agenda of the current policy debate.

\section{Findings of the Literature and Hypotheses of Interest}

(a) The School-to-Work Literature

The literature on school-to-work transitions can be grouped in a British, a German, and an internationally oriented tradition. In the latter category OECD (1998) evaluates the determinants of employment and unemployment probabilities of school leavers across countries. The findings point to the importance of age, gender, educational attainment, overall labor market tightness, and particular institutional settings such as employment protection legislation, or apprenticeship systems. McIntosh (1998) investigates the changes in post-secondary education participation in four countries and finds only a small effect of the overall labor market situation on transitions into continued training. Instead, changes in initial academic attainment and expected returns to schooling seem to be decisive factors.

The British literature is mostly concerned with the post-compulsory education choice of young people. The typical approach in these studies is to estimate logit models of the determinants of continued education. The contributions are then distinguished either by their rich and comprehensive datsets, or by specialized focuses: Based on data from the Family Expenditure Survey, Rice (1987) finds differential effects of household income for males and females, and discusses the introduction of public education subsidies. Micklewright (1989) looks at a representive sample of the birth cohort of 1958 using data from the National Child Development Study and is able to confirm that family background effects remain influential even when detailed controls for student ability are considered. 
Whitfield and Wilson (1991) use a different approach and interprete aggregate time series evidence to support the introduction of special employment and training measures for youth. Rice (1999) exploits a vast dataset with over 50,000 observations on school leavers. She confirms the relevance of individual academic attainment, as well as of family and social background. Also, she provides evidence on the relevance of regional labor market tightness and dynamics particularly for the educational decisions of low ability males. Leslie and Drinkwater (1999) devote particular attention to the situation of ethnic minorities and find that this groups' higher probability of participating in continued education is related to higher expected future benefits and fewer current opportunities. Dustmann et al. (1998) investigate the effects of school quality on the level of education achieved where higher pupilteacher-ratios promote continued full-time education. The study most closely related to the empirical approach followed below is that by Andrews and Bradley (1997). These authors model a wide set of transitions open to school leavers using a multinomial logit estimator. They look at the population of 14,000 school leavers of Lancashire in 1991, confirm the relevance of local labor market variables, and show that the characteristics of the previous school are influential for transitions.

In contrast to the British studies German analyses of school-to-work transitions addressed a broader set of issues, including institutional design and comparisons of educational outcomes with e.g. the United States (Buechtemann et al. 1993, 1994, Gitter and Scheuer 1997, Lindner 1998). More relevant to this analysis are four recent papers: The study by Franz et al. (1997) describes German institutions and recent trends. Since youth unemployment is more pressing for those above age 20, the authors focus on young individuals, who completed vocational training. The analysis first investigates the duration of a subsequent non-employment spell, and finds a large impact of family background variables. Second it finds that failures during or after vocational training have long run consequences for individual incomes. The authors do not consider controls for regional or labor market conditions.

The study by Inkmann et al. (1998) uses three cross-sections of a career survey to analyze the earnings effects of failures in the transition from apprenticeship to work. Based on theories of human capital theory and asymmetric information, the authors predict individuals to be permanently hurt by an 
early failure in the labor market. They find this hypothesis confirmed, with early unemployment experiences being more detrimental in the long run than failures in completing apprenticeships. Again, the estimations omit controls for regional and labor market effects and focus instead on characteristics of the employer and individual human capital. The authors emphasize the importance of supporting young labor market participants at the "second hurdle" after completion of an apprenticeship.

A different aspect of labor market transitions is investigated by Franz and Zimmermann (1999). Again, the analysis focuses on individuals who completed an apprenticeship, only now to evaluate the determinants of (i) the probability of being hired by the firm providing the apprenticeship training, and (ii) the duration of a subsequent first employment spell. The authors control for individual and firm level effects, for the national unemployment and the national apprentice rate, i.e. the number of apprentices per employed person. Both indicators suggest that labor market tightness reduces the expected duration of a first employment spell.

The last German study under review focuses on a different subgroup of German youth: Those who graduated from the Gymnasium and choose between academic and vocational training. Merz and Schimmelpfennig (1999) take a sample of about 400 Gymnasium graduates from the German Socioeconomic Panel and test whether skill-specific wage differentials and unemployment rates affect transition decisions. The authors omit controls for regional effects but point out that the small size of their sample does not permit detailed region indicators. They find clear responses particularly in male career choices to the expected returns from career paths.

This review of the literature on school-to-work transitions shows that the issues addressed so far are rather specific to certain subgroups, and that the role of regional effects has not been studied. The contribution of this study is to fill this gap in the literature.

(b) Theoretical Background

Most studies on the transition decision of school leavers refer to the human capital model as a basic framework for the empirical analysis. Following human capital theory investments in education 
are determined based on the comparison of expected costs and expected benefits of additional training. The costs combine direct costs such as tuition payments and indirect costs such as foregone leisure and consumption, while benefits are typically summarized as the expected change in lifetime incomes. Rice (1999), and Merz and Schimmelpfennig (1999) explicitly formulate dynamic optimization models to motivate the role of determinants of transition decisions. If we assume that each school leaver can choose among various alternatives (e.g. employment, apprenticeship, or other vocational training), then the individual chooses the option, which generates the highest expected lifetime utility.

In principle, expected lifetime utility in each type of post-secondary schooling is determined by characteristics of the individual as well as by those of the alternative options which, however, are typically not observed. The literature distinguishes three groups of factors, the ones relating to the individual, to social and family background, and characteristics of the local labor market. Individual characteristics account for the individuals' age at the time of completing secondary education, their sex, nationality, health, and educational attainment. The type of secondary school in combination with age controls for individual ability, which is expectedly higher for Gymnasium and middle school graduates than for basic school graduates, and for a given degree should be higher for those who graduate at an earlier age. While the British literature showed that the probability of continued education is higher for females than for males, such a prediction does not seem warranted for Germany: Given the young age of school leavers, labor force exits for family reasons should be infrequent. Since ethnic background might affect educational choice - be it through cultural differences or differences in human capital such as language abilities - foreign origin ought to be considered. Finally, youngsters with a handicap might be particularly disadvantaged and face a limited choice in the vocational training market.

The studies reviewed above provide ample evidence for the relevance of family background in educational transitions. The structure of a household might at least in part indicate its permanent income and the degree of financial restrictions school leavers face in their transition decision. Thus, we 
control for whether the school leaver lives in a single parent or two parent household. Since Micklewright (1989) and Andrews and Bradley (1997) show that the number of younger siblings plays a role for youth educational choices, this indicator is considered as well. Parental background is likely to affect the tastes and preferences of the offspring as well as to influence their academic attainment in secondary school. Therefore we control for the impact of parental education, ethnic background, and labor force status.

Finally, regional and labor market indicators may be important factors in school leavers' transition decisions. These variables have not been considered in German school-to-work studies, but the international literature clearly speaks to their relevance. ${ }^{4}$ The measures considered here describe the region of an individuals' residence by the size of the community, the local unemployment rate, and an indicator of whether it is in East or West Germany. The underlying hypothesis is that the size and structure of the local labor market affects youth behavior. Clearly, perfect mobility would render such effects irrelevant, but particularly for young school leavers financial constraints may restrict mobility. In that case we expect youth to be more likely to find a job or an apprenticeship the larger the local labor market and the more extensive labor demand. If someone lives in a small village, the next employment possibility may be much harder to reach than for a comparable youth in a major city. The same rationale applies to transitions to academic training. Whereas youth living in a major town might have the opportunity to study while living at home, academic training may be much more costly for those living in countryside villages. In addition to the regional indicators (East vs. West German location reflects similar differences) the consideration of unemployment rates permits a more direct control for labor market effects.

\footnotetext{
${ }^{4}$ Micklewright (1989) finds significant differences in educational choices of school leavers in London and Wales from those in the rest of the country. Rice (1999) finds highly significant differences in the educational choices of students in different areas of the country, as well as by local labor market conditions.
} 


\section{Data Description and Empirical Method}

(a) The Data

The data for this study is taken from the first 14 waves of the German Socioeconomic Panel (GSOEP, 1984-1997). The sample is restricted to individuals aged 15 to 25 . Observations are censored when the individual does not respond to a survey, when measures on core variables such as age, sex, type of school, or household identifiers are missing, or when the interview was incompletely conducted.

The dependent variable of the analysis describes the individuals' training or employment status at the time of the interview in the year after leaving secondary school. To generate this variable, one first has to determine in which year the person left school. There are two ways to determine schooling status within the GSOEP: The first is based on a survey question where the individual (if above age 16) is asked about current participation in schooling or training activities and about the type of schooling currently pursued. We consider an individual as in school if either Grundschule, Sonderschule, Hauptschule, Realschule, Gymnasium or Gesamtschule are indicated. ${ }^{5}$ For individuals under age 16 information on current schooling is gathered in the household interview from the household head. A school exit is coded if an individual was in school in one year and out of school in the next year. The second way to determine schooling status is based on a question, which asks individuals annually whether they obtained a degree in the preceding calendar year. 68 percent of all school exits were identified by both indicators. In cases where the coding procedure resulted in more than one exit from secondary school, only the school exit indicated last was considered, assuming that the intermittent failure to indicate school attendance resulted from measurement error. ${ }^{6}$

A wide set of alternative transitions is available for school leavers. It ranges from continued schooling in vocational schools, polytechnical schools, and universities over immediate employment,

${ }^{5}$ For a description of these institutions see section 2 above. Sonderschule provides special education for those unable to pass basic school. Grundschule is elementary school.

${ }^{6}$ About twenty percent of all observations were affected by multiply coded school exits. 
apprenticeship, military or substitute service for men, to unemployment, or out of the labor force spells. These alternatives are captured in the dependent variable. Even though there are numerous options, the recent German school-to-work literature concentrates on transitions into apprenticeship programs and labor market outcomes of those graduating from apprenticeship programs (e.g. Franz 1997, Inkmann et al. 1998, or Franz and Zimmermann 1999). Similarly, Merz and Schimmelpfennig (1999) only looked at two transitions for Gymnasium graduates. Taking a more comprehensive approach, this study considers all school leavers and models transitions into the following comprehensive set of activities:

(1) fulltime or parttime employment without training,

(2) apprenticeship,

(3) vocational training without employment,

(4) university or polytechnical schools,

(5) military or substitute service for men,

(6) unemployment or out of the labor force.

Military and substitute service are considered as endogenous outcomes, because it is possible to influence the timing of these activities. While unemployment and out of the labor force are typically separate outcomes, they are combined here, because school leavers have no claim to unemployment benefits and because unemployed seekers of apprenticeship positions are not defined as unemployed.

The distribution of the 2,702 school leavers across these states are presented in Table 3 by various characteristics. Almost half of all graduates take up an apprenticeship, and 22 percent seek vocational training through the alternatives offered in the vocational schooling system. The shares of individuals in non-training employment, in academictraining, and military / substitute service are below ten percent each. A substantial fraction of about 12 percent of all school leavers is either unemployed or out of the labor force one year after exiting secondary school.

The main difference between the two sexes lies in the share of immediate transitions into academic training, which naturally is higher among females, as male Gymnasium leavers are typically drafted immediately. More surprisingly, the share of nonemployed females clearly exceeds the sample average. The comparison between East and West German transitions yields a substantially higher 
coverage of East German youth with training programs: Jointly 76 percent of East German school leavers are in vocational training, compared to 66 percent in the West. This is balanced by a higher share of West German youth in nonemployment one year after finishing school. While the latter outcome seems surprising in view of much higher overall unemployment in East vs. West Germany, Figures 2 and 3 do suggest that the difference in unemployment rates for youth under age 20 is indeed minor.

The comparison of transitions by national origin shows substantive differences, in that immigrant youth have much higher probabilities of immediate employment and nonemployment than native youth. Panel B of Table 3 describes transition distributions by community size, health, and regional unemployment. Most striking are the high nonemployment rates in large communities, and the sensitivity to state unemployment rates. Health does not appear to be strongly correlated with transition decisions. Panel $\mathrm{C}$ shows the distribution of transitions by type of school and agegroup. Nonemployment rates are highest for those in 'other' schools (including special education, and comprehensive schools). Transition into military or substitute service is highest among Gymnasium leavers because they reach draft age when leaving school. This difference by agegroup is also reflected in the last two columns of panel C.

Panel D presents the distribution of destination states for different periods to provide a rough first indication of the effects of policy changes. After 1990 the benefit program for academic training became more generous, but the share of transitions into academics increased only slightly for women and not at all for men. Based on changes in military policies discussed above we would expect a decline in the share of male graduates making a transition to the military after 1990, and again an increase in the most recent years. These developments are indeed borne out by the frequency distributions.

The independent variables considered in the multivariate analysis are described in Table 4 for the male and female subsamples, which differ only marginally. Among the individual characteristics age, nationality, type of school attended, and health as measured by whether the person suffers from 
a handicap, are considered. While individual characteristics are measured as of the year after the transition, when the dependent variable is observed, parent and household characteristics are gathered in the last year of school attendance, i.e. before the transition to avoid endogeneity problems. Parent characteristics reflect the socioeconomic background of the youth. They combine the level of parent education, nationality, and employment status. Since parent information could not be matched for all school leavers, separate indicators are considered if that information is missing and the missing values of the parent variables are set to zero. The data provides information on a parent-child relationship only between the youth and the head of household. It is assumed that the household's partner is the other parent. ${ }^{7}$ Three household characteristics are considered: The number of young siblings and whether it is a single or a two parent household. Since single parent households are typically headed by females, a higher share of father than of mother information is missing.

The set of regional and labor market indicators are East versus West German location, state unemployment rate, and size of the community. The state unemployment rates follow the East / West trends as depicted in Figures 2 and 3. The majority of school leavers covered in the data resides in communities with less than 50,000 inhabitants. The distribution of school leavers across community sizes closely matches the aggregate figures for Germany (STBA 1998).

\section{(b) Empirical Method}

A multinomial logit model is applied to investigate the relevance of various determinants of school leavers' transition decision. This estimator provides a very flexible approach for the problem at hand, as all possible transitions can be considered and no a priori restrictions are imposed on the parameters and the set of transition alternatives. However, two features of the model must be discussed before the estimation results can be laid out.

7 In addition, parent information was used, which was explicitly gathered in the survey of 1986. For individuals under the age of 16 the survey identifies both parents directly. This information was used as well, but is available only for a minute share of school leavers. 
The first concerns the "independence of irrelevant alternatives (IIA)" assumption which underlies the multinomial logit estimator. Under the IIA assumption the odds of chosing one transition over another are independent of the set of alternative transitions considered in the model. If the IIA assumption does not hold for the considered outcome measures, this may lead to inconsistent estimates. Hausman and McFadden (1984) introduce a Wald test of the IIA hypothesis, which was performed here for the male and female subsamples. The results are presented in Table 5. For women the test results suggest that the null hypothesis i.e. that the IIA assumption does hold, could not be rejected. For the male sample this was not the case. When outcomes 2 (apprenticeship training) or 4 (academic training) were eliminated from the set of alternatives, the null hypothesis was rejected at high significance levels. Therefore the outcomes apprenticeship, vocational, and academic training were combined to an adjusted version of the dependent variable, for which the IIA hypothesis could not be rejected (see Table 5). ${ }^{8}$

Second, a problem pointed out by Moulton (1990) must be addressed. In models where aggregate information on regions, such as state unemployment rates, is considered jointly with characteristics of individuals, the disturbance terms may be correlated within aggregation groups, i.e. within states. Moulton (1990) shows that this can bias the estimated standard errors downwards. To address this problem a nonparametric random effects estimator, as developed by Heckman and Singer (1984), was applied to the multinomial logit estimator. This estimator permits tests for correlation among the unobservables for individuals in a given state (Riphahn 1999 provides a more detailed description of this estimator). The test was performed separately for the male and female samples. Permitting state specific correlations in theerror terms of the male subsample did not yield a statistically significant improvement of the likelihood function, in the case of the female sample it did. ${ }^{9}$ Therefore

\footnotetext{
8 Initial adjustments of combining smaller subsets of transition outcomes did not satisfy the IIA assumption.

${ }^{9}$ For the male sample the log likelihood could not be improved beyond the value of 888.20 obtained before, in the female case the consideration of controls for correlated errors improved the log likelihood from a value of $1,455.55$ to $1,449.56$, which is statistically significant at the 5 percent level given that 5 additional parameters were
} 
Tables 6 and 7 present the standard multinomial logit estimation results for men and results with corrected standard errors for women. ${ }^{10}$ The next section discusses the determinants of transition choices.

\section{Results}

The estimated models differ in that the model for women does not contain the transitions into military or substitute service and that the transitions into further training (apprenticeship, vocational, and academic training) are considered jointly in the model for men. The interpretation of the coefficients in this type of model is complicated because they describe the probability of each of the considered outcomes relative to the omitted category - here the transition to apprenticeship training - and because the signs of coefficients can differ from those of marginal effects. Therefore, the interpretation first evaluates the statistical significance of the estimates, and second interprets the substantive evidence based on simulation results.

The statistical significance of the coefficients is evaluated separately for each outcome, and jointly across the entire model. Tables 6 and 7 present both, with the last column indicating the results of hypotheses tests for the entire model. The indicators for age and prior schooling have the most significant impact on transition outcomes for both subsamples. ${ }^{11}$ Jointly they represent potent indicators of student ability, as weaker students may take additional years before they are able to graduate from

estimated.

10 The final specification was chosen based on preliminary estimations. These showed that a different health indicator did not yield any results different from those presented, that a richer set of indicators for parent schooling degrees, and the consideration of parents' age, or of immigrant students' language capacity did not significantly add to the explanatory power of the model, that unemployment rates measured at a more disaggregated level had less explanatory power, than the state level ones, and that a variable controlling for the number of persons living in a household did not significantly improve the model fit.

11 The schooling coefficients in the model for a transition into military service were restricted to zero, because the fact that Gymnasium graduates have reached draft age at graduation compared to the younger graduates from the other school types caused an unreasonably large coefficient in this model. To provide an indirect test for the potential endogeneity of the school type, estimations without these variables were performed. The results did not differ in major ways. 
a given secondary school. Of high overall statistical significance are the indicators for parents' education and employment status. The effect of these variables is well established in the German (Merz and Schimmelpfennig 1999) and British (Rice 1999) literature. ${ }^{12}$ Also, in the model for men the indicators for the number of children yield surprisingly significant influences on labor market transitions.

Among the regional effects we observe significant differences between the transition probabilities of the East and West German samples. The state unemployment rate, which is hypothesized to affect transitions through the availability ofemployment and training opportunities and at the same time as a determinant of the expected future payoff of additional training, is not jointly statistically significant in either subsample, and only one individual effect is precisely estimated. This outcome is sensitive to the consideration of year fixed effects in the model (not shown in Tables 6 and 7, but jointly highly significant): In models, which considered only a linear timetrend instead of the fixed effect control, the state unemployment rate was jointly significant for both subsamples. Finally, the indicators of the size of an individual's community of residence are jointly significant.

The nonlinearity of the estimator does not permit a reliable interpretation of the magnitude and direction of the estimated coefficients. To aid interpretation, Table 8 presents simulations of the variables' effects on the transition probabilities. The simulation results are obtained in two steps. First, the baseline probabilities are predicted for each observation based on the estimated coefficients. The average predicted probabilities (first rows in the panels of Table 8) are identical to the observed probabilities (Table 3.A). In a second step single variables were set to fixed values for all observations and the predictions were repeated. The difference in the predicted probabilities, e.g. between the transition probability when "foreign origin" is set to 1 minus the probability when it is set to 0 for each observation, is divided by the baseline probability. Thus, the figures in Table 8 indicate differences in

\footnotetext{
${ }^{12}$ It appears to be a striking advantage of the GSOEP data that it provides indicators for parent educational status. The studies by Inkmann et al.(1998) and Franz and Zimmermann (1999) are based on a dataset with more observations, but which apparently does not permit this type of control. Only Franz et al. (1997) are able to consider controls for the vocational background of the household head, which they find to be influential. Neither partner information nor the educational status of the household head are considered.
} 
transition probabilities due to the variables' effect, measured in percent of the baseline probabilities. The relative impact of the variables is comparable across transition alternatives and subsamples. Since the transition intononemployment is of prominent policy relevance, the discussion mostly focuses on the last columns in Table 8. A first finding is that the explanatory variables frequently have effects of different magnitudes on the probability of nonemployment for the two sexes. Being of foreign origin rather than native, increases both samples' probability of nonemployment, but the effect on females is almost three times as large as that on men. The consequence of a handicap shows the same pattern. The probability of nonemployment increases by 48 percent for handicapped men and about doubles for handicapped women. However, the underlying coefficients are not precisely determined.

The schooling effects on the probability of a transition into nonemployment go in the expected direction: The higher the level of schooling, the less likely school leavers are to find themselves in nonemployment. Only the effect of middle versus basic school for men does not fit the pattern, but this coefficient is not precisely estimated. For females those with middle school or Gymnasium degrees have lower risks of nonemployment relative to basic schooling. Those for females captured in the "other school" category have an elevated risk of nonemployment, but also a surprisingly high transition probability into academic training.

Independent of the country of origin of the school leavers themselves, the nationality of their parents has a sizeable effect on youth labor market outcomes. If both parents are non-natives, the probability of nonemployment increases by 29 percent for men and by again a more sizeable 41 percent for women. Also, all country of origin effects (for parents and the youth themselves) yield an increased probability of immediate employment after leaving school. These results raise concerns, as they show that independent of the youth's ability, their ethnic background seems to hinder transitions into continued training. The effects of non-native ethnicity in the British data are typically reverse, where Rice (1999) and Andrews and Bradley (1997) show that non-whites have higher probabilities of participating in continued education.

The indicator of the number of young siblings in the household has a significant and sizeable 
effect on the transitions into nonemployment for men. Having one versus no child under age 16 in the household increases the probability of nonemployment (as well as of immediate employment) by about 20 percent. The indicator has not been considered in the German literature so far, however, the results confirm Micklewright (1989), who finds that youth with more siblings have a higher probability of dropping out of continued education. The mechanism behind this effect is likely to be related to parents' financial and time constraints. The more siblings are there to care for, the fewer financial resources are available to finance continued education of an older child, or to support job search activities. ${ }^{13}$ This same pattern is likely to be behind the result, which shows that youths from two parent households have much lower chances of falling into nonemployment than those from single parent households. For men also the probability of immediate employment falls and that of continued training increases, if they come from a two as opposed to a single parent household.

Next, regional and labor market effects are to be addressed. Confirming the distribution already presented in Table 3 and discussed above, youth in East Germany has a lower probability of nonemployment than youth in the West. East German men have a high transition probability into military service, an about equal probability of training, and a much lower probability of starting employment immediately after leaving school. For East German females the probability of academic training exceeds that of women in the West by far, a phenomenon which is likely to be related to higher female labor force participation and thus higher expected lifetime returns to education in East compared to West Germany.

As would have been expected, the aggregate unemployment rate at the state level yields sizeable effects on transitions into nonemployment. Again, female school leavers are more strongly affected by a given change in state unemployment than their male classmates. Women's transition probabilities intoimmediate employmentalsodecline drastically if aggregate unemployment is high. The effect on male youths surprisingly points in the opposite direction. Their negative response in the

${ }^{13}$ For women this conclusion is somewhat counterbalanced by the higher probability of a transition into vocational or academic training. 
probability of a transition to military service, when unemployment is high, is also difficult to rationalize. For femalesthe probability of taking up apprenticeship training declines in times of high unemployment and that of other vocational training increases, a plausible pattern, as the availability of apprenticeship positions should be correlated to the overall labor market tightness.

The community size effects are evaluated by comparing transition probabilities in smaller communities with those for a metropolitan center. Generally four patterns emerge. First, the overall probability of nonemployment is largest in the metropolitan center, most clearly for the male sample, confirming the description in Table 3(B). Second, the probability of taking up military service is lowest for young men in metropolitan areas. Third, the probability of a transition into immediate employment for men is lowest in the metropolitan area. Fourth, the probability of a transition into vocational or academic training for women is particularly low in metropolitan areas, where a wider pool of apprenticeship positions might be available instead. It appears that school leavers outside of major metropolitan centers make up for a lack of apprenticeship positions by chosing vocational school based or academic training. For women in midsized towns this pattern is quite clear. ${ }^{14}$

Finally, the policy effects ought to be interpreted. The first hypothesis to be tested is that the probability of taking up academic training increased after the generosity of the Bafög benefit system was expanded in 1990. The bivariate probability distributions in Table 3(D) indicated no such effect for men, actually exactly the contrary, and only a slight increase in the probability of academic training for females. In the multivariate framework this correlation can only beexamined for the female sample,

\footnotetext{
${ }^{14}$ Critics may argue that the community effects are subject to the reflection problem pointed out by Manski (1993). He argues that the effect of (the characteristics of) an aggregate, e.g. a state, on the behavior of a unit of observation typically cannot be identified. For our case this implies that parents' decision to move e.g. to a large town is determined by similar factors and motives as the later outcome of their child's post-school transition. One precondition for such an argument to hold is that households can indeed be observed to move. The dataset generated before defining the transition variable, contained panel information on a multitude of households with and without a graduating youth, before and after a possible graduation. In this dataset, with more than 90,000 household-year observations, 0.74 percent of the observations moved between states. In the final sample the share of moving households dropped to 0.1 percent, suggesting that very little moving takes place. Overall the argument that the decision of parents to move between states is correlated with a transition decision of their children at a possibly much later date is not convincing. Therefore endogenous moves are not likely to bias the results presented above.
} 
since the dependent variable for men combines academic training with other outcomes. The simulations suggest that there is no increase in the probability of taking up academic training after 1990, in fact, the probability declined drastically for women, while at the same time the probability of apprenticeship training and nonemployment increased.

The second policy hypothesis refers to changes in military policy. The above discussion suggests that the probability of a transition to the military or substitute service should be high before 1990, decline immediately after the cold war for a few years, until it rises again in the last years covered in the data. Averaging the predicted probabilities of a transition into military service over the relevant periods yields a mean probability of 11.6 percent for $1985-90$, a mean probability of 8.6 for 1991-93, and a mean probability of 17.2 for 1994-97. These figures are not presented in Table 8 but indicate a close correlation with the pattern expected based on the described policy changes.

\section{Conclusion}

Motivated by the increasing attention of labor market policies to the youth unemployment problem, this study investigates labor market transitions of secondary school leavers in Germany. Using a detailed dataset and a flexible modelling approach, the determinants of such transitions are evaluated. As potentially influential factors characteristics of the youth, household, and parents, as well as indicators of the region of residence, and local labor markets are considered.

The findings confirm many of the conclusions from the British school-to-work literature. Overall the most significant effects are those describing the ability level of the individual, as reflected in the indicators of age and type of school. The latter expectedly yields that the probability of nonemployment is least for those youth with the highest completed degree. The results permit conclusions as to the groups most vulnerable to the risk of nonemployment, or of foregoing continued education: Youth with a handicap and immigrants suffer substantial nonemployment problems. The latter effect is obtained based both on the country of origin of the individual as well as on the parents', and it is consistent in both, the male and female subsamples. 
Two findings that are new to the literature are that the educational attainment of parents has a statistically significant effect on youth labor market transitions and that youth from two-parent families are ina much better position to take up vocational training after secondary school than individuals from single parent families, an outcome which holds particularly for young men. The simulation results do not yield a correlation of the probability of taking up academic training with policy changes in the studentbenefit program in 1990 . However, the development in mens' participation in military service over time seem to reflect the trends in military policy.

With respect to regional and local labor market effects living in a high unemployment states is correlated with higher risks of nonemployment for school leavers. Given state unemployment rates, the risk of nonemployment is highest for youth in large metropolitan areas. These results seem to suggest that youth labor market policies should focus on disadvantaged regions with tight overall labor markets, emphasize metropolitan areas, and possibly pay particular attention to the needs of immigrant youth. 
Table 1: Unemployment by Agegroup, Country, Year, and Sex

\begin{tabular}{lrrrrrrrr}
\hline Country & \multicolumn{3}{c}{ 1990 Unemployment Rates } & \multicolumn{4}{c}{1998 Unemployment Rates } \\
& All & \multicolumn{3}{c}{ Youth (Age 15-24) } & All & \multicolumn{2}{c}{ Youth (Age 15-24) } \\
& (15-64) & All & Men & Women & (15-64) & All & Men & Women \\
\hline France & 9.2 & 19.1 & 15.3 & 23.9 & 11.9 & 25.4 & 21.9 & 30 \\
Germany & 4.9 & 4.6 & 4.4 & 4.7 & 8.6 & 9.4 & 10.4 & 8.2 \\
Greece & 7.2 & 23.3 & 15.1 & 32.6 & 11.9 & 32.1 & 23.1 & 42.4 \\
Ireland & 13.2 & 17.6 & 18.9 & 16.1 & 7.9 & 11.5 & 11.9 & 11.1 \\
Italy & 9.9 & 28.9 & 23.4 & 35.4 & 12.2 & 32.1 & 28.1 & 37.2 \\
Japan & 2.2 & 4.3 & 4.5 & 4.1 & 4.2 & 7.7 & 8.2 & 7.3 \\
Netherlands & 7.4 & 11.1 & 10 & 12.3 & 4.3 & 8.2 & 7.8 & 8.7 \\
Spain & 16.1 & 30.1 & 23.2 & 39.7 & 18.8 & 34.1 & 27.1 & 43.4 \\
United Kingdom & 6.8 & 10.1 & 11.1 & 9 & 6.2 & 12.3 & 13.8 & 10.5 \\
United States & 5.7 & 11.2 & 11.6 & 10.7 & 4.5 & 10.4 & 11.1 & 9.8 \\
\hline European Union & 8.1 & 15.7 & 13.5 & 18.1 & 9.9 & 19.1 & 17.6 & 20.8 \\
Total OECD & 5.9 & 11.5 & 11.1 & 12.1 & 6.8 & 12.8 & 12.5 & 13.1 \\
\hline
\end{tabular}

Source: $\quad$ OECD Employment Outlook June 1999.

Table 2: Youth Unemployment Relative to Total Unemployment by Country, Year, and Sex

\begin{tabular}{lrrrrrr}
\hline Country & & \multicolumn{1}{c}{1990} & & & 1998 & \\
& All & Men & Women & All & Men & Women \\
\hline France & 2.08 & 1.66 & 2.6 & 2.13 & 1.84 & 2.52 \\
Germany & 0.94 & 0.9 & 0.96 & 1.09 & 1.21 & 0.95 \\
Greece & 3.24 & 2.1 & 4.53 & 2.7 & 1.94 & 3.56 \\
Ireland & 1.33 & 1.43 & 1.22 & 1.46 & 1.51 & 1.41 \\
Italy & 2.92 & 2.36 & 3.58 & 2.63 & 2.3 & 3.05 \\
Japan & 1.96 & 2.05 & 1.86 & 1.83 & 1.95 & 1.74 \\
Netherlands & 1.50 & 1.35 & 1.66 & 1.91 & 1.81 & 2.02 \\
Spain & 1.87 & 1.44 & 2.47 & 1.81 & 1.44 & 2.31 \\
United Kingdom & 1.49 & 1.63 & 1.32 & 1.98 & 2.23 & 1.69 \\
United States & 1.97 & 2.04 & 1.88 & 2.31 & 2.47 & 2.18 \\
\hline European Union & 1.94 & 1.67 & 2.24 & 1.93 & 1.78 & 2.1 \\
Total OECD & 1.95 & 1.88 & 2.05 & 1.88 & 1.84 & 1.93 \\
\hline
\end{tabular}

Note: Figures present youth unemployment rate (age 15-24) relative to overall unemployment rate across all agegoups, both as presented in Table A. Values smaller than 1 indicate that youth unemployment is below average unemployment, values bigger than 1 describe the reverse situation. - German figures for 1990 refer to West Germany, for 1998 to East and West Germany.

Source: Own calculations based on OECD Employment Outlook June 1999. 
Table 3: Distribution of School Leavers across Destination States by Characteristics (in percent)

\begin{tabular}{lrrrrrrr}
\hline A & All & Males & Females & East & West & Native & Immigrants \\
Employed & & & Germans & Germans & \multicolumn{1}{c}{$\mathrm{s}$} & \\
Apprenticeship & 6.1 & 6.0 & 6.2 & 2.0 & 6.7 & 4.9 & 13.1 \\
Vocational Training & 45.6 & 46.7 & 44.4 & 62.4 & 43.1 & 46.9 & 37.8 \\
Academic Training & 21.8 & 20.1 & 23.6 & 13.8 & 23.0 & 21.7 & 22.4 \\
Military & 8.2 & 6.3 & 10.1 & 7.6 & 8.3 & 8.7 & 5.0 \\
Not employed & 6.3 & 12.3 & - & 7.1 & 6.2 & 7.3 & 1.0 \\
\hline Number of Obs. & 12.0 & 8.6 & 15.7 & 7.1 & 12.8 & 10.5 & 20.7 \\
\hline
\end{tabular}

\begin{tabular}{lrrrrrrr}
\hline B & All & \multicolumn{2}{c}{ Community Size } & \multicolumn{2}{c}{ Health } & \multicolumn{2}{c}{ State Unemployment } \\
& & Small & Large & Good & Poor & Low & High \\
\hline Employed & 6.1 & 6.1 & 6.0 & 5.8 & 7.3 & 6.9 & 5.3 \\
Apprenticeship & 45.6 & 46.9 & 44.7 & 46.2 & 42.9 & 44.6 & 46.6 \\
Vocational Training & 21.8 & 25.4 & 19.3 & 21.8 & 21.7 & 24.9 & 18.9 \\
Academic Training & 8.2 & 6.7 & 9.3 & 8.3 & 7.7 & 7.8 & 8.5 \\
Military & 6.3 & 6.4 & 6.3 & 6.2 & 7.1 & 6.5 & 6.1 \\
Not employed & 12.0 & 8.5 & 14.5 & 11.8 & 13.3 & 9.3 & 14.6 \\
\hline Number of Obs. & 2,702 & 1,112 & 1,590 & 2,236 & 466 & 1,302 & 1,400 \\
\hline
\end{tabular}

\begin{tabular}{|c|c|c|c|c|c|c|c|}
\hline \multirow[t]{2}{*}{$\mathrm{C}$} & \multirow[t]{2}{*}{ All } & \multicolumn{4}{|c|}{----------------- Type of School ----------------- } & \multicolumn{2}{|c|}{ Age } \\
\hline & & Basic & Middle & Highest & Other & under 19 & 19 or above \\
\hline Employed & 6.1 & 6.9 & 4.7 & 6.8 & 6.0 & 3.1 & 10.1 \\
\hline Apprenticeship & 45.6 & 47.5 & 61.7 & 23.9 & 41.2 & 53.4 & 34.7 \\
\hline Vocational Training & 21.8 & 32.3 & 21.1 & 9.7 & 24.7 & 29.9 & 10.7 \\
\hline Academic Training & 8.2 & 0.2 & 1.4 & 27.6 & 2.2 & 1.3 & 17.7 \\
\hline Military & 6.3 & - & 0.2 & 22.9 & 0.6 & - & 15.1 \\
\hline Not employed & 12.0 & 13.0 & 10.8 & 9.1 & 25.3 & 12.3 & 11.6 \\
\hline Number of Obs. & 2,702 & 854 & 933 & 733 & 182 & 1,568 & 1,134 \\
\hline
\end{tabular}

\begin{tabular}{lrrrrrr}
\hline $\mathrm{D}$ & All & \multicolumn{2}{c}{ Women } & \multicolumn{3}{c}{ Men } \\
& & $1985-90$ & $1991-97$ & $1985-90$ & $1991-94$ & $1995-97$ \\
\hline Employed & 6.1 & 7.02 & 5.45 & 7.38 & 6.03 & 3.01 \\
Apprenticeship & 45.6 & 42.81 & 45.81 & 44.14 & 54.52 & 43.37 \\
Vocational Training & 21.8 & 25.25 & 22.21 & 21.56 & 16.16 & 21.39 \\
Academic Training & 8.2 & 9.70 & 10.47 & 7.81 & 6.58 & 3.01 \\
Military & 6.3 & - & - & 12.01 & 10.14 & 15.36 \\
Not employed & 12.0 & 15.22 & 16.06 & 7.09 & 6.58 & 13.86 \\
\hline Number of Obs. & 2,702 & 598 & 716 & 691 & 365 & 332 \\
\hline
\end{tabular}

Note: $\quad$ Communities with at least 20,000 inhabitants are defined as "large." State unemployment is "low" if in the considered year it remains under 9 percent.

Source: $\quad$ Own calculations based on GSOEP. 
Table 4: Descriptive Statistics of Explanatory Variables

\begin{tabular}{|c|c|c|c|c|c|}
\hline \multirow[t]{2}{*}{ Variable } & \multirow[t]{2}{*}{ Description } & \multicolumn{2}{|c|}{ Men } & \multicolumn{2}{|c|}{ Women } \\
\hline & & Mean & St.Dev. & Mean & St.Dev. \\
\hline \multicolumn{6}{|c|}{ Individual Characteristics } \\
\hline Age & Age in years & 18.581 & 1.786 & 18.574 & 1.647 \\
\hline Foreign & Born abroad $(0 / 1)$ & 0.154 & 0.361 & 0.139 & 0.346 \\
\hline Handicap & Handicapped $(0 / 1)$ & 0.099 & 0.299 & 0.079 & 0.270 \\
\hline Basic School & Last school: basic school $(0 / 1)$ & 0.372 & 0.483 & 0.257 & 0.437 \\
\hline Middle School & Last school: middle school $(0 / 1)$ & 0.285 & 0.451 & 0.409 & 0.492 \\
\hline Gymnasium & Last school: Gymnasium (0/1) & 0.275 & 0.447 & 0.267 & 0.443 \\
\hline Other School & Last school: other school $(0 / 1)$ & 0.068 & 0.253 & 0.066 & 0.249 \\
\hline \multicolumn{6}{|c|}{ Characteristics of Parents } \\
\hline F high education & Father has advanced degree $(0 / 1)$ & 0.281 & 0.450 & 0.264 & 0.441 \\
\hline M high education & Mother has advanced degree $(0 / 1)$ & 0.273 & 0.446 & 0.265 & 0.442 \\
\hline F Foreign & Father born abroad $(0 / 1)$ & 0.323 & 0.468 & 0.276 & 0.447 \\
\hline M Foreign & Mother born abroas $(0 / 1)$ & 0.325 & 0.469 & 0.296 & 0.456 \\
\hline F Employed & Father currently employed $(0 / 1)$ & 0.793 & 0.405 & 0.724 & 0.447 \\
\hline M Employed & Mother currently employed (0/1) & 0.540 & 0.499 & 0.490 & 0.500 \\
\hline F Missing & Father information missing $(0 / 1)$ & 0.102 & 0.303 & 0.187 & 0.390 \\
\hline M Missing & Mother information missing $(0 / 1)$ & 0.048 & 0.213 & 0.097 & 0.296 \\
\hline \multicolumn{6}{|c|}{ Characteristics of Household } \\
\hline No. of children & No. of children < age 16 in household & 1.052 & 1.114 & 0.967 & 1.060 \\
\hline Single Parent & Single parent household $(0 / 1)$ & 0.086 & 0.280 & 0.101 & 0.302 \\
\hline Two Parent & Two parent household $(0 / 1)$ & 0.890 & 0.313 & 0.821 & 0.383 \\
\hline \multicolumn{6}{|c|}{ Regional and Labor Market Indicator } \\
\hline East & Residence in East Germany $(0 / 1)$ & 0.122 & 0.327 & 0.140 & 0.347 \\
\hline Unempl. Rate & State unemployment rate & 9.463 & 3.630 & 9.553 & 3.745 \\
\hline Community 1 & Community $<5,000$ inhabitants $(0 / 1)$ & 0.184 & 0.388 & 0.178 & 0.383 \\
\hline Community 2 & Community $5-20,000$ inhabitants $(0 / 1)$ & 0.229 & 0.420 & 0.232 & 0.422 \\
\hline Community 3 & Community $20-50,000$ inhabitants $(0 / 1)$ & 0.180 & 0.384 & 0.181 & 0.385 \\
\hline Community 4 & Community $50-100,000$ inhabitants $(0 / 1)$ & 0.099 & 0.299 & 0.091 & 0.287 \\
\hline Community 5 & Community $100-500,000$ inhabitants $(0 / 1)$ & 0.156 & 0.363 & 0.175 & 0.380 \\
\hline Community 6 & Community $>500,000$ inhabitants $(0 / 1)$ & 0.151 & 0.358 & 0.144 & 0.351 \\
\hline \multicolumn{2}{|c|}{ Number of observations } & \multicolumn{2}{|c|}{1,388} & \multicolumn{2}{|c|}{1,313} \\
\hline
\end{tabular}


Table 5 Results of the Hausman Test for Independence of Irrelevant Alternatives

\begin{tabular}{|c|c|c|c|c|c|c|}
\hline \multirow[t]{2}{*}{ Omitted Category } & \multicolumn{2}{|c|}{ Men - Original Version } & \multicolumn{2}{|c|}{ Men - Adjusted Version } & \multicolumn{2}{|c|}{ Women - Original Version } \\
\hline & Test Statistic & p - Value & Test Statistic & $\mathrm{p}$ - Value & Test Statistic & p - Value \\
\hline 1 Employed & -20.16 & (a) & -1.32 & (a) & -2.57 & (a) \\
\hline 2 Apprenticehip & $4,116.50$ & 0.00 & (b) & (b) & 127.63 & 0.13 \\
\hline 3 Vocational Train. & -191.46 & (a) & -60.82 & (a) & -34.28 & (a) \\
\hline 4 Academic Train. & 776.38 & 0.00 & (b) & (b) & -7.50 & (a) \\
\hline 5 Military & -6.76 & (a) & 0.19 & 1.00 & - & - \\
\hline 6 Not employed & $-3,991.34$ & (a) & 79.75 & 0.25 & -4.64 & (a) \\
\hline
\end{tabular}

Note: (a) The test statistic takes on a negative value, which can be interpreted as strong evidence against rejecting the null hypothesis that the IIA assumption holds.(Hausman and McFadden, 1984, footnote 4, or Stata 6 Manual, volume 2, p.12)

(b) This outcome is combined with outcome 3 in the adjusted version of the model. 
Table 6: Estimation Results Men

\begin{tabular}{|c|c|c|c|c|c|c|c|c|}
\hline \multirow{2}{*}{$\begin{array}{l}\text { Transition to: } \\
\text { (relative to training) }\end{array}$} & \multirow{2}{*}{\multicolumn{2}{|c|}{$\begin{array}{l}\text { Employment } \\
\text { Coeff. Std.Err. }\end{array}$}} & \multirow{2}{*}{\multicolumn{2}{|c|}{$\begin{array}{r}\text { Military Service } \\
\text { Coeff. Std.Err. }\end{array}$}} & \multirow{2}{*}{\multicolumn{2}{|c|}{$\begin{array}{l}\text { Nonemployment } \\
\text { Coeff. Std.Err. }\end{array}$}} & \multicolumn{2}{|c|}{ Joint Test } \\
\hline & & & & & & & $\div^{2}$ & p-Value \\
\hline \multicolumn{9}{|c|}{ Individual Characteristics } \\
\hline Age & $0.751 * *$ & * 0.097 & $0.904 * *$ & $* 0.076$ & $0.256^{* *}$ & 0.093 & $172.95^{* *}$ & $* 0.000$ \\
\hline Foreign & 0.486 & 0.343 & -0.048 & 0.663 & 0.269 & 0.317 & 2.54 & 0.468 \\
\hline Handicap & -0.721 & 0.965 & -1.388 & 1.394 & 0.243 & 0.567 & $172.95^{* *}$ & $* 0.000$ \\
\hline Middle School & -0.141 & 0.344 & - & - & 0.177 & 0.276 & & \\
\hline Gymnasium & $-1.093 * *$ & $* 0.421$ & - & - & -0.363 & 0.389 & $26.00 * *$ & $* 0.000^{\mathrm{a}}$ \\
\hline Other School & 0.651 & 0.519 & - & - & $1.202 * *$ & 0.337 & & \\
\hline \multicolumn{9}{|c|}{ Characteristics of Parents } \\
\hline F high education & 0.176 & 0.346 & $0.561 *$ & 0.254 & 0.053 & 0.277 & $16.31 *$ & $0.012^{\mathrm{b}}$ \\
\hline M high education & 0.454 & 0.386 & $0.607 *$ & 0.255 & 0.130 & 0.296 & & \\
\hline F Foreign & -0.385 & 0.838 & -0.161 & 0.504 & -0.347 & 0.408 & $31.34 * *$ & $* 0.000^{b}$ \\
\hline M Foreign & -0.054 & 0.959 & $-1.838 * *$ & $* 0.521$ & 0.504 & 0.390 & & \\
\hline F Employed & -0.163 & 0.383 & $0.890 *$ & 0.445 & -0.359 & 0.310 & 10.27 & $0.114^{\mathrm{b}}$ \\
\hline M Employed & $0.511 \mathrm{R}$ & 0.272 & -0.170 & 0.232 & -0.009 & 0.224 & & \\
\hline F Missing & -0.385 & 0.838 & 0.869 & 0.702 & $-1.533^{*}$ & 0.689 & $11.03 \mathrm{R}$ & $0.088^{\mathrm{b}}$ \\
\hline M Missing & -0.054 & 0.959 & $-1.309 R$ & 0.794 & -0.841 & 0.759 & & \\
\hline \multicolumn{9}{|c|}{ Characteristics of Household } \\
\hline No. of children & $0.234 *$ & 0.116 & $-0.330 *$ & 0.163 & $0.163 R$ & 0.099 & $11.27 *$ & 0.010 \\
\hline Single Parent & 0.493 & 1.185 & 1.464 & 0.998 & -0.044 & 0.799 & 2.29 & 0.514 \\
\hline Two Parents & 0.185 & 1.305 & 1.156 & 1.106 & -1.445 & 1.019 & 4.02 & 0.259 \\
\hline \multicolumn{9}{|c|}{ Regional and Labor Market Indicator } \\
\hline East & -1.001 & 0.852 & 0.444 & 0.545 & $-1.410 *$ & 0.576 & $8.43 *$ & 0.038 \\
\hline Unempl. Rate & 0.057 & 0.059 & -0.081 & 0.053 & 0.054 & 0.050 & 5.02 & 0.170 \\
\hline Community 1 & $0.900 \mathrm{R}$ & 0.494 & 0.213 & 0.419 & -0.528 & 0.393 & & \\
\hline Community 2 & 0.304 & 0.420 & 0.410 & 0.414 & $-0.987 * *$ & 0.353 & & \\
\hline Community 3 & -0.606 & 0.501 & 0.034 & 0.406 & -0.457 & 0.321 & $23.49 \mathrm{R}$ & $0.074^{\mathrm{c}}$ \\
\hline Community 4 & 0.533 & 0.469 & 0.576 & 0.450 & -0.620 & 0.395 & & \\
\hline Community 5 & 0.220 & 0.421 & 0.016 & 0.407 & $-0.818^{*}$ & 0.354 & & \\
\hline Constant & $-18.542 * *$ & $* 2.637$ & $-21.324 * *$ & $* 2.181$ & $-5.346^{*}$ & 2.241 & & \\
\hline
\end{tabular}

Note: Coefficients for the transition into apprenticeship, vocational or academic training are restricted to zero. Reference categories are basic school, and the largest community size. The estimations control for a set of year dummies (jointly significant at the 2 percent level). **, *, and $\mathrm{R}$ indicate statistical significance at the 1, 5, and 10 percent level. Joint significance tests are performed across all alternatives and in case (a) for all three types of schooling, (b) for both parents, and (c) for all community sizes. 
Table 7: Estimation Results Women

\begin{tabular}{|c|c|c|c|c|c|c|c|c|c|c|}
\hline \multirow{2}{*}{$\begin{array}{l}\text { Transition to: } \\
\text { (rel. to Apprent.) }\end{array}$} & \multicolumn{2}{|c|}{ Employment } & \multicolumn{2}{|c|}{ Vocational } & \multicolumn{2}{|c|}{ Academic } & \multicolumn{2}{|c|}{ Nonemployment } & \multicolumn{2}{|c|}{ Joint Test } \\
\hline & Coeff. & S.E. & Coeff. & S.E. & Coeff. & S.E. & Coeff. & S.E. & $\div^{2} \quad \mathrm{p}$ & p-Value \\
\hline \multicolumn{11}{|c|}{ Individual Characteristics } \\
\hline Age & $0.474 * *$ & 0.101 & $-0.571 * *$ & 0.091 & $0.297 *$ & 0.120 & 0.002 & 0.084 & $86.69 * *$ & $* 0.000$ \\
\hline Foreign & 0.570 & 0.440 & 0.277 & 0.296 & -0.241 & 0.683 & $0.759 * *$ & 0.295 & $9.52 *$ & 0.049 \\
\hline Handicap & -0.612 & 0.797 & -0.385 & 0.670 & -2.510 & 1.924 & 0.541 & 0.664 & 4.60 & 0.330 \\
\hline Middle School & $-0.775 R$ & 0.455 & $-0.458 *$ & 0.231 & 1.184 & 1.102 & $-0.658 *$ & 0.287 & & \\
\hline Gymnasium & -0.571 & 0.639 & $1.077 * *$ & 0.385 & $4.690 * *$ & 1.078 & 0.009 & 0.440 & $99.36 * *$ & $* 0.000^{\mathrm{a}}$ \\
\hline Other School & -0.444 & 0.792 & 0.056 & 0.443 & 1.971 & 1.296 & 0.509 & 0.464 & & \\
\hline \multicolumn{11}{|c|}{ Characteristics of Parents } \\
\hline F high education & -0.365 & 0.427 & $0.374 \mathrm{R}$ & 0.209 & 0.504 & 0.333 & -0.111 & 0.262 & $20.42 \mathrm{R}$ & $0.009^{b}$ \\
\hline M high education & 0.481 & 0.450 & 0.250 & 0.232 & $0.834^{*}$ & 0.378 & 0.203 & 0.293 & & \\
\hline F Foreign & -0.411 & 0.625 & 0.386 & 0.381 & 0.345 & 0.735 & 0.479 & 0.474 & 12.13 & $0.145^{\mathrm{b}}$ \\
\hline M Foreign & 0.789 & 0.638 & 0.030 & 0.375 & 0.437 & 0.702 & 0.227 & 0.481 & & \\
\hline F Employed & -0.385 & 0.511 & -0.184 & 0.299 & 0.855 & 0.609 & $-0.545 R$ & 0.303 & $14.71 \mathrm{R}$ & $0.065^{\mathrm{b}}$ \\
\hline M Employed & -0.571 & 0.357 & -0.140 & 0.173 & -0.423 & 0.328 & -0.332 & 0.206 & & \\
\hline F Missing & 0.470 & 0.765 & -0.446 & 0.672 & 1.243 & 0.799 & -0.346 & 0.592 & 9.84 & $0.277^{\mathrm{b}}$ \\
\hline M Missing & 0.362 & 0.677 & -0.911 & 0.572 & 0.104 & 0.781 & -0.014 & 0.532 & & \\
\hline \multicolumn{11}{|c|}{ Characteristics of Household } \\
\hline No. of children & 0.182 & 0.154 & 0.109 & 0.087 & 0.155 & 0.181 & 0.086 & 0.102 & 3.37 & 0.498 \\
\hline Single Parent & -0.876 & 0.793 & 0.332 & 0.651 & 0.514 & 0.804 & -0.144 & 0.603 & 3.30 & 0.508 \\
\hline Two Parents & 0.321 & 0.750 & -0.531 & 0.795 & 0.836 & 0.812 & -0.545 & 0.697 & 3.75 & 0.440 \\
\hline \multicolumn{11}{|c|}{ Regional and Labor Market Indicator } \\
\hline East & -0.175 & 0.906 & $-1.059 *$ & 0.462 & 0.703 & 0.795 & $-1.234 *$ & 0.564 & $12.69 *$ & 0.013 \\
\hline Unempl. Rate & -0.058 & 0.068 & 0.047 & 0.042 & -0.085 & 0.069 & $0.083 R$ & 0.048 & 7.02 & 0.135 \\
\hline Community 1 & -0.036 & 0.548 & 0.070 & 0.379 & -0.342 & 0.642 & -0.236 & 0.424 & & \\
\hline Community 2 & 0.363 & 0.454 & 0.470 & 0.343 & $1.051 *$ & 0.495 & -0.002 & 0.350 & & \\
\hline Community 3 & -0.408 & 0.563 & 0.316 & 0.347 & 0.408 & 0.615 & 0.242 & 0.350 & $34.00 *$ & $0.026^{\mathrm{c}}$ \\
\hline Community 4 & 0.285 & 0.596 & 0.679 & 0.399 & 0.982 & 0.670 & 0.382 & 0.407 & & \\
\hline Community 5 & 0.329 & 0.508 & $0.605 R$ & 0.361 & $1.829 * *$ & 0.505 & 0.424 & 0.363 & & \\
\hline Constant & $-8.695^{* *}$ & 2.197 & $9.760 * *$ & 1.915 & $-9.199 * *$ & 2.901 & 0.136 & 1.798 & & \\
\hline Rho & -1.140 & 0.746 & -0.191 & 0.591 & $-3.494 * *$ & 0.762 & -0.772 & 0.538 & $11.97 *$ & 0.035 \\
\hline
\end{tabular}

Note: Coefficients for the transition into an apprenticeship are restricted to zero, the columns labelled SE present standard errors. Reference categories are basic school, and the largest community size. The estimations control for a set of year dummies (jointly significant at the 1 percent level). **, *, and R indicate statistical significance at the 1, 5, and 10 percent level. Joint significance tests are performed across all alternatives and in case (a) for all three types of schooling, (b) for both parents, and (c) for all community sizes. 
Table 8: $\quad$ Simulation Results - Determinants of Transitions Into:

0: apprenticeship and vocational training and academic training $\quad$ 1: employment $\quad$ 2: apprenticehip 3: vocational training $\quad$ 4: academic training $\quad$ 5: military or substitute service $\quad$ 6: nonemployment

\begin{tabular}{|c|c|c|c|c|c|}
\hline A: Men -- Transition into: & 0 & 1 & 5 & \multicolumn{2}{|l|}{6} \\
\hline Baseline Probability & 0.731 & 0.060 & 0.123 & \multicolumn{2}{|c|}{0.086} \\
\hline \multicolumn{6}{|l|}{ Individual Characteristics } \\
\hline Foreign Origin (1 vs. 0) & -0.050 & 0.522 & -0.097 & \multicolumn{2}{|c|}{0.239} \\
\hline Handicap (1 vs. 0$)$ & 0.174 & -0.456 & -0.866 & \multicolumn{2}{|c|}{0.483} \\
\hline School: Middle vs. Basic School & -0.005 & -0.196 & -0.005 & \multicolumn{2}{|c|}{0.187} \\
\hline School: Gymnasium vs. Basic School & 0.087 & -0.926 & 0.087 & \multicolumn{2}{|c|}{-0.234} \\
\hline School: Other School vs. Basic School & -0.185 & 0.798 & -0.185 & \multicolumn{2}{|c|}{1.671} \\
\hline \multicolumn{6}{|l|}{ Parent and Household Characteristics } \\
\hline Both Parents of Foreign Origin (1 vs. 0) & 0.110 & 1.787 & -2.632 & \multicolumn{2}{|c|}{0.291} \\
\hline No. of children under 16 in household ( 1 vs. 0 ) & 0.015 & 0.234 & -0.436 & \multicolumn{2}{|c|}{0.171} \\
\hline Household Type: Two Parents vs. Single Parent & 0.218 & -0.067 & -0.076 & \multicolumn{2}{|c|}{-1.993} \\
\hline \multicolumn{6}{|l|}{ Regional and Labor Market Characteristics } \\
\hline Region: East vs. West Germany & 0.077 & -0.705 & 0.642 & \multicolumn{2}{|c|}{-0.970} \\
\hline Unemployment: 13 vs. 6 percent & 0.014 & 0.421 & -0.569 & \multicolumn{2}{|c|}{0.397} \\
\hline Community Size: $<5 \mathrm{~K}$ vs. $>500 \mathrm{~K}$ Inhabitants & -0.032 & 1.209 & 0.161 & \multicolumn{2}{|c|}{-0.798} \\
\hline Community Size: $<20 \mathrm{~K}$ vs. $>500 \mathrm{~K}$ Inhabitants & 0.022 & 0.342 & 0.441 & \multicolumn{2}{|c|}{-1.151} \\
\hline Community Size: $<50 \mathrm{~K}$ vs. $>500 \mathrm{~K}$ Inhabitants & 0.074 & -0.361 & 0.093 & \multicolumn{2}{|c|}{-0.593} \\
\hline Community Size: <100K vs. >500K Inhabitants & -0.039 & 0.561 & 0.577 & \multicolumn{2}{|c|}{-0.900} \\
\hline Community Size: <500K vs. >500K Inhabitants & 0.067 & 0.293 & 0.070 & \multicolumn{2}{|c|}{-0.983} \\
\hline Policy Effects (before 1991 vs. after 1991) & -0.046 & -0.495 & 0.243 & \multicolumn{2}{|c|}{0.621} \\
\hline B: Women -- Transition into: & 1 & 2 & 3 & 4 & 6 \\
\hline Baseline Probability & 0.063 & 0.426 & 0.229 & 0.123 & 0.158 \\
\hline \multicolumn{6}{|l|}{ Individual Characteristics } \\
\hline Foreign Origin (1 vs. 0) & 0.410 & -0.211 & 0.058 & -0.409 & 0.687 \\
\hline Handicap (1 vs. 0$)$ & -0.331 & 0.202 & -0.176 & -1.318 & 1.058 \\
\hline School: Middle vs. Basic School & -0.904 & 0.335 & -0.188 & 1.225 & -0.513 \\
\hline School: Gymnasium vs. Basic School & -1.560 & -0.563 & 0.588 & 13.225 & -0.734 \\
\hline School: Other School vs. Basic School & -0.987 & -0.156 & -0.083 & 1.687 & 0.626 \\
\hline \multicolumn{6}{|l|}{ Parent and Household Characteristics } \\
\hline Both Parents of Foreign Origin (1 vs. 0) & 0.037 & -0.311 & 0.090 & 0.405 & 0.412 \\
\hline No. of children under 16 in household (1 vs. 0) & 0.108 & -0.068 & 0.042 & 0.069 & 0.019 \\
\hline Household Type: Two Parents vs. Single Parent & 0.985 & 0.195 & -0.818 & 0.401 & -0.191 \\
\hline \multicolumn{6}{|l|}{ Regional and Labor Market Characteristics } \\
\hline Region: East vs. West Germany & 0.126 & 0.345 & -0.601 & 1.395 & -0.724 \\
\hline Unemployment: 13 vs. 6 percent & -0.488 & -0.082 & 0.243 & -0.635 & 0.511 \\
\hline Community Size: $<5 \mathrm{~K}$ vs. $>500 \mathrm{~K}$ Inhabitants & 0.024 & 0.066 & 0.111 & -0.166 & -0.183 \\
\hline Community Size: $<20 \mathrm{~K}$ vs. $>500 \mathrm{~K}$ Inhabitants & -0.261 & 0.142 & 0.228 & 0.789 & -0.242 \\
\hline Community Size: <50K vs. >500K Inhabitants & -0.478 & -0.145 & 0.183 & 0.215 & 0.135 \\
\hline Community Size: <100K vs. >500K Inhabitants & -0.355 & -0.070 & 0.354 & 0.562 & 0.043 \\
\hline Community Size: <500K vs. $>500 \mathrm{~K}$ Inhabitants & -0.132 & -0.433 & 0.167 & 1.785 & -0.023 \\
\hline Policy Effects (before 1991 vs. after 1991) & 0.019 & 0.122 & -0.054 & -1.471 & 0.275 \\
\hline
\end{tabular}

Note: The figures describe the deviation between the two predicted probabilities relative to the baseline probability and can be interpreted as percentage deviation from the baseline due to changes in variables. 
Figure 1: Distribution of School Leavers by Secondary School Track

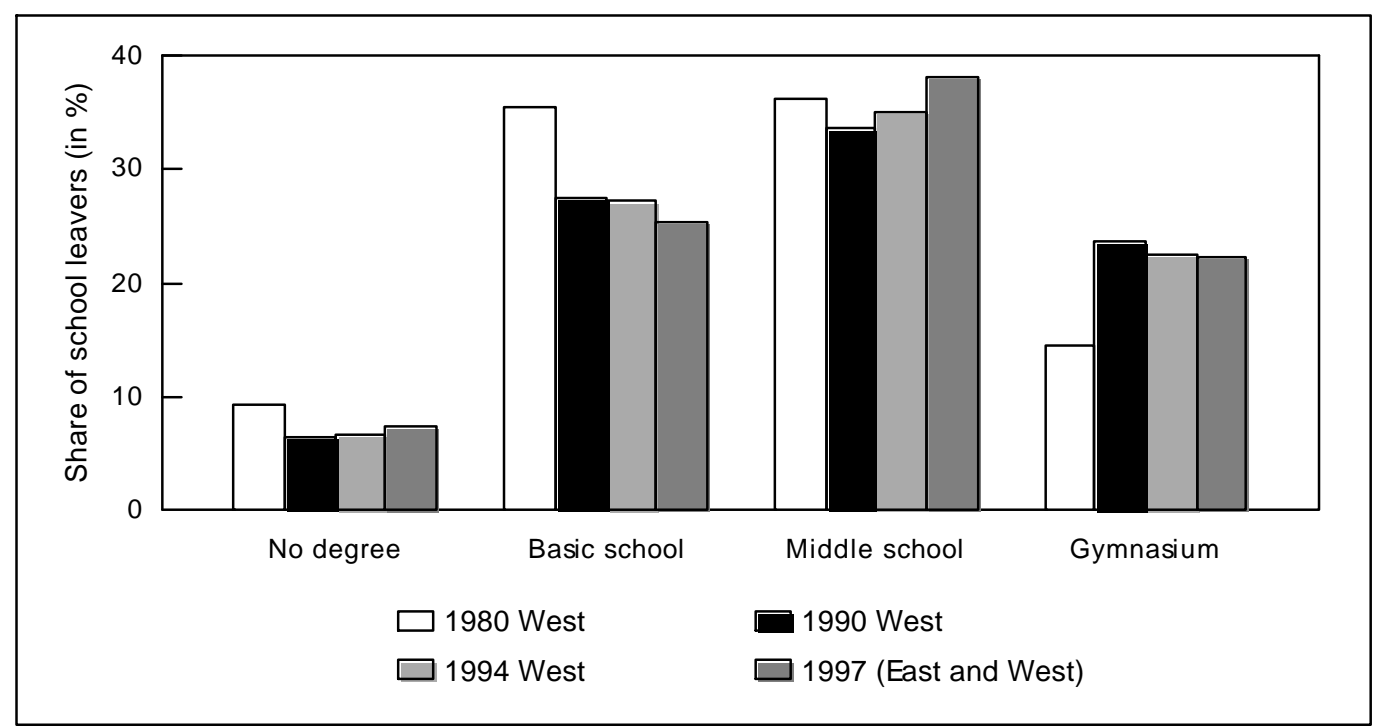

Source: Institut der deutschen Wirtschaft, 1999, Zahlen zur wirtschaftlichen Entwicklung der Bundesrepublik Deutschland, Table 126.

Figure 2: New University Students as Share of Gymnasium Graduates (in percent)

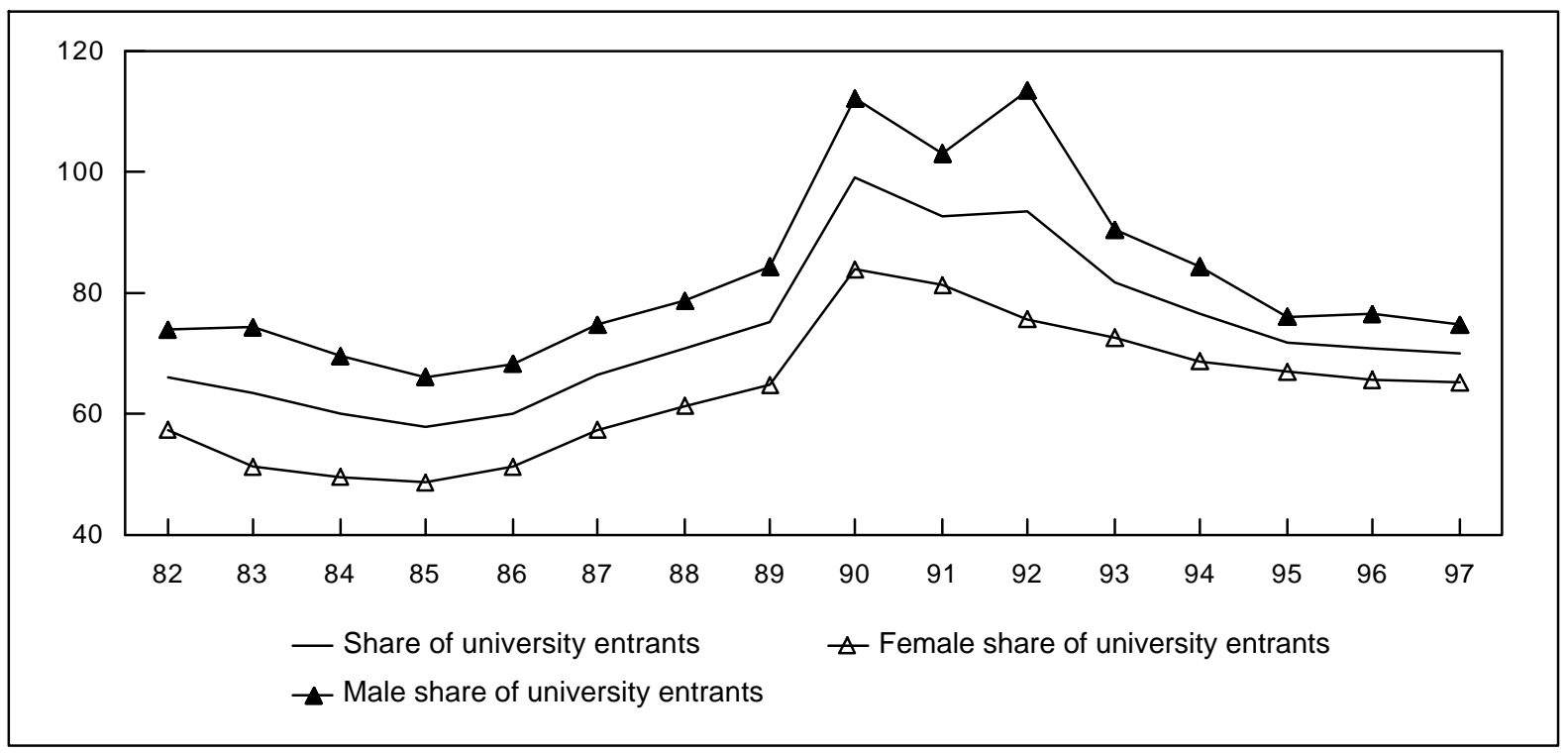

Source: Statistisches Bundesamt, Statistical Yearbook of the Federal Republic of Germany, various years.

Note: (1) The ratios do not depict the share of Gymnasium graduates moving on immediately to academic training. Instead the number of new university students (as of the winter semester) is divided by the number of Gymnasium graduates of the same year. Since military service or other vocational training might intervene between leaving school and taking up university studies in some years the ratio can take on values above one.

(2) Through 1990 the figures represent West Germany only, after 1991 they represent united Germany. 
Figure 3: West German Unemployment Rates by Agegroup

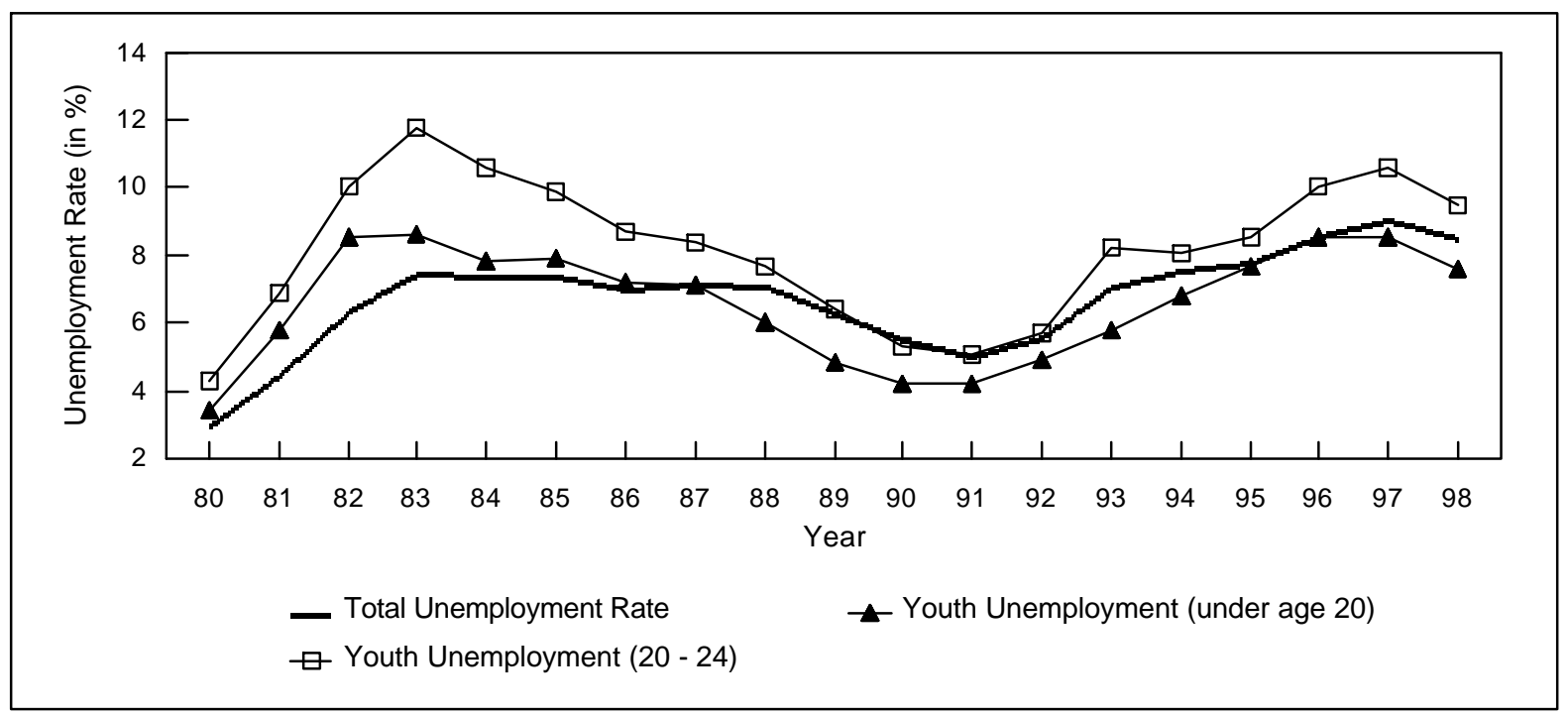

Source: $\quad$ see Figure 4

Figure 4: East German Unemployment Rates by Agegroup

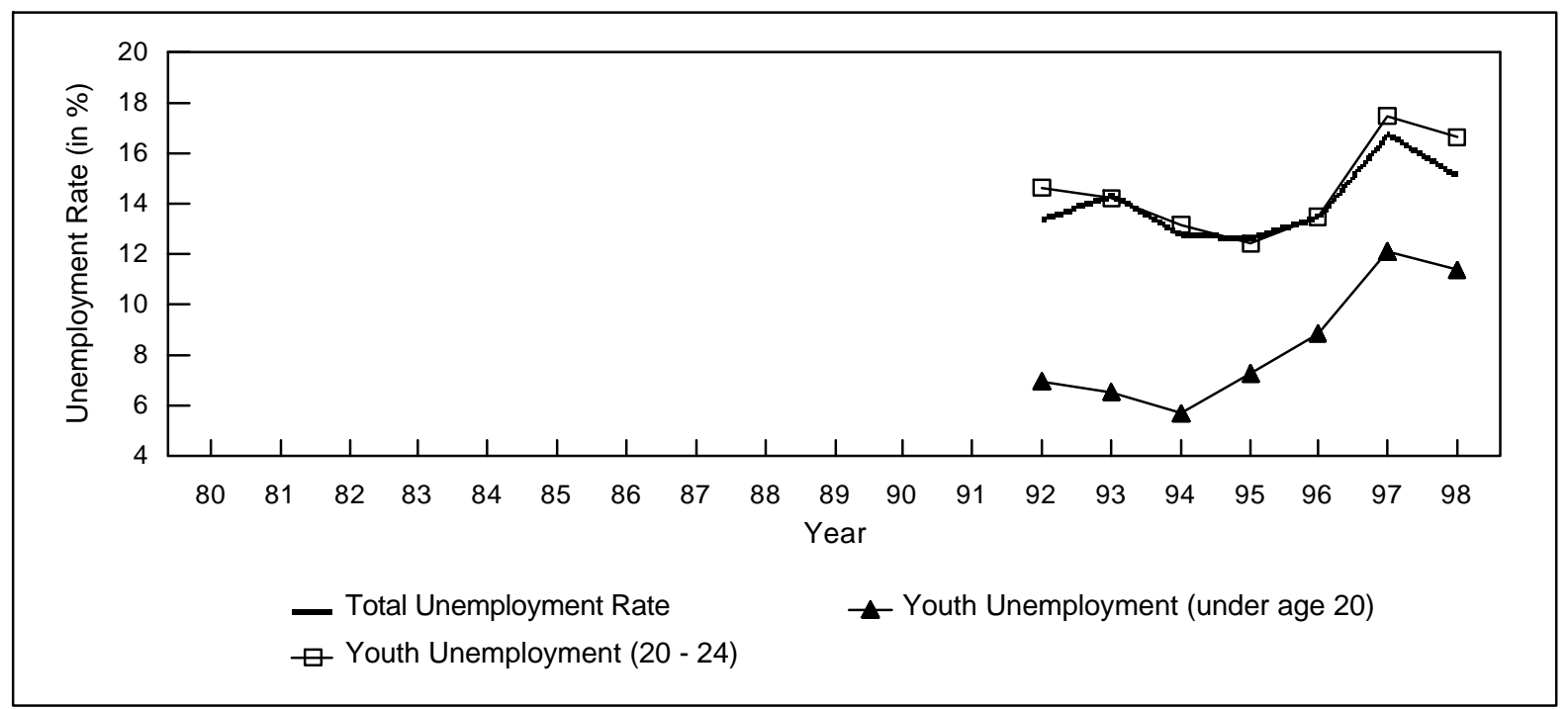

Source: Own calculations based on the number of registered unemployed as of September (Bundesanstalt für Arbeit, Strukturanalyse 1993 and Bundesanstalt für Arbiet, Strukturanalyse 1998), and the labor force as of April (Statistisches Bundesamt, Fachserie 1, Reihe 4.1.1). 
Figure 5: Averaged Youth Unemployment (under Age 20) Relative to Total Unemployment by Area and City States

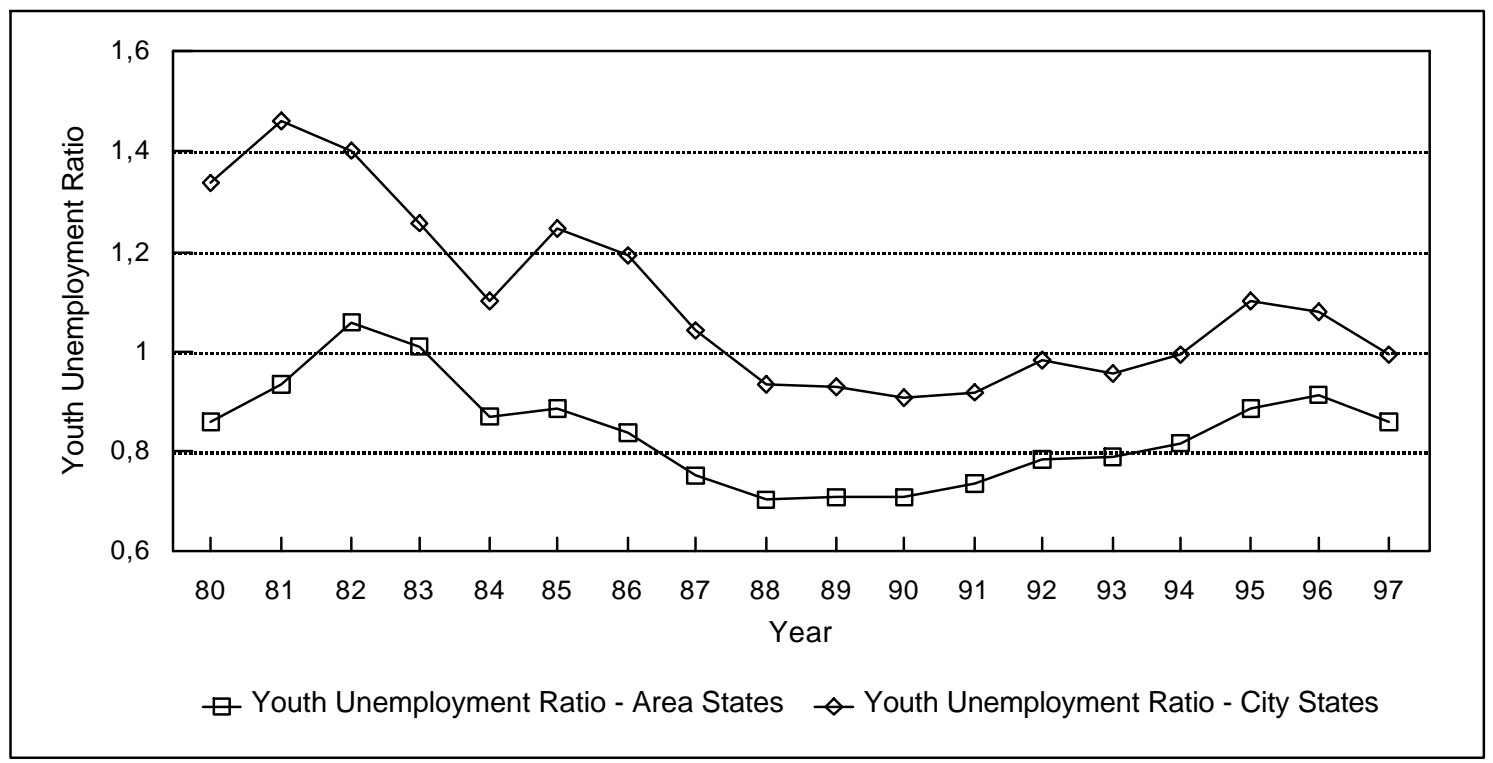

Source: Own calculations based on state unemployment rates (Bundesanstalt für Arbeit, Amtliche Nachrichten der Bundesanstalt für Arbeit: Jahreszahlen 1988 and Bundesanstalt für Arbeit, Amtliche Nachrichten der Bundesanstalt für Arbeit: Jahreszahlen 1997) 


\section{References}

Andrews, Martyn and Steve Bradley, 1997, Modelling the Transition from School and the Demand for Training in the United Kingdom, Economica 64(255), 387-413.

BMA (Bundesministerium für Arbeit und Sozialordnung), 1995, Übersicht über das Sozialrecht, Bonn. BMBF (Bundesministerium für Bildung und Forschung), 1999, Berufsbildungsbericht 1999, Bonn. BREG (Bundesregierung), 1996, Jahresbericht der Bundesregierung 1996, Bonn.

Buechtemann, Christoph F., Jürgen Schupp, and Dana Soloff, 1993, Roads to work: School-to-work Transition Patterns in Germany and the United States, Industrial Relations Journal 24(2), 97 111.

Buechtemann, Christoph F., Jürgen Schupp, and Dana Soloff, 1994, From School to Work: Patterns in Germany and the United States, in : Johannes Schwarze, Friedrich Buttler, and Gert G. Wagner (eds.) Labour Market Dynamics in Present Day Germany, 112-141.

Clinton, William J. and Al Gore, 1992, Putting People First: A National Economic Strategy for America, Business Week Sept. 7 1992, 30.

Dustmann, Christian, Najma Rajah, and Arthur van Soest, 1998, School Quality, Exam Performance, and Career Choice, CentER Discussion Paper No. 9816, Tilburg, The Netherlands.

Ellwood, David T., 1982, Teenage Unemployment: Permanent Scars or Temporary Blemishes? in: Richard B. Freeman and David A. Wise (eds.), The Youth Labor Market Problem: Its Nature, Causes and Consequences, The University of Chicago Press, Chicago, 349-385.

Franz, Wolfgang, Joachim Inkmann, Winfried Pohlmeier, Volker Zimmermann, 1997, Young and Out in Germany: On the Youths' Chances of Labor Market Entrance in Germany, NBER Working Paper No. 6212.

Franz, Wolfgang, and Volker Zimmermann, 1999, Mobilität nach der beruflichen Ausbildung: Eine empirische Studie für Westdeutschland, ZEW Discussion Paper No. 99-21.

Freeman, Richard B. and William M. Rodgers III, 1999, Area Economic Conditions and the Labor Market Outcomes of Young Men in the 1990s Expansion, NBER Working Paper No. 7073.

Frerich, Johannes and Marti Frey, 1996, Handbuch der Geschichte der Sozialpolitik in Deutschland. Band 3, Verlag Oldenbourg, München, second edition.

Gitter, R.J. and M. Scheuer, 1997, U.S. and German Youths: Unemployment and the Transition from School to Work, Monthly Labor Review 120(3), 16-20.

Hausman, Jerry A. and Daniel McFadden, 1984, Specification Tests for the Multinomial Logit Model, Econometrica 52(5), 1219-1240.

Heckman, James J. and Burton Singer, 1984, A Method for Minimizing the Impact of Distributional Assumptions in Econometric Models for Duration Data, Econometrica 52(2), 271-320.

Inkmann, Joachim, Stefan Klotz, and Winfried Pohlmeier, 1998, Growing into Work: Pseudo Panel Data Evidence on Labor Market Entrance in Germany, ZEW Discussion Paper No. 98-47.

Leslie, Derek, and Stephen Drinkwater, 1999, Staying on in Full-Time Education: Reasons for Higher Participation Rates Among Ethnic Minority Males and Females, Economica 66(261), 63-77.

Lindner, Axel, 1998, Modelling the German System of Vocational Education, Labour Economics 5(4), 411-423.

Manski, Charles F. , 1993, Identification of Endogenous Social Effects: The Reflection Problem, Review of Economic Studies 60, 531-542.

McIntosh, Steven, 1998, The Demand for Post-Compulsory Education in Four European Countries, London School of Economics, Centre for Economic Performance Discussion Paper No. 393.

Merz, Monika, and Axel Schimmelpfennig, 1999, Career Choices of German High School Graduates: Evidence from the German Socio-Economic Panel, European University Institute Working Paper No. 99/11.

Micklewright, John, 1989, Choice at Sixteen, Economica 56(221), 25-39.

Moulton, Brent, 1990, An Illustration of a Pitfall in Estimating the Effects of Aggregate Variables on Micro Units, Review of Economics and Statistics 72(2), 334-338. 
OECD (Organisation for Economic Co-Operation and Development), 1998, OECD Employment Outlook 1998 - Chapter 3: Getting Started, Settling in: The Transition from Education to the Labour Market, Paris, 81-122.

OECD (Organisation for Economic Co-Operation and Development), 1999a, OECD Economic Surveys: France 1999, Paris.

OECD (Organisation for Economic Co-Operation and Development), 1999b, OECD Employment Outlook 1999 - Editorial, Paris, 7-11.

Rice, Patricia, 1987, The Demand for Post-compulsory Education in the UK and the Effects fo Educational Maintenance Allowances, Economica 54(216), 465-476.

Rice, Patricia, 1999, The Impact of Local Labour Markets on Investment in Further Education: Evidence from the England and Wales Youth Cohort Studies, Journal of Population Economics 12(2), 287-312.

Riphahn, Regina T., 1999, Disability Retirement Among German Men in the 1980s, Industrial and Labor Relations Review 52(4), 628-647.

Rotte, Ralph, 1996, Das Ende der Wehrpflicht in Europa?, Merkur 50, 460-465.

SVR (Sachverständigenrat), 1998, Jahresgutachten 1998/99 des Sachverständigenrates zur Begutachtung der gesamtwirtschaftlichen Entwicklung, Deutscher Bundestag Drucksache $14 / 73$.

STBA (Statistisches Bundesamt), 1998, Statistisches Jahrbuch für die Bundesrepublik Deutschland 1998, Metzler Poeschel, Wiesbaden.

Whitfield, Keith and R. Wilson, 1991, Staying on in Full-time Education: The Educational Participation Rate of 16 Year Olds, Economica 58(231), 391-404. 